\section{Oral Mucositis in Pediatric Oncology Patients: A Nested Case- Control to a Prospective Cohort}

Isabella Lima Arrais Ribeiro ${ }^{1}{ }^{\circ}$, Ana Carolina Rodrigues de Melo ${ }^{2}$, Nayara Pereira Limão ${ }^{2}$, Paulo Rogério Ferreti Bonan ${ }^{3}$, Eufrásio de Andrade Lima Neto $^{4}$, Ana Maria Gondim Valença ${ }^{3(\mathbb{B}}$

\author{
'Department of Social Medicine, \\ USP - Universidade de São \\ Paulo, Ribeirão Preto, Brazil \\ 2UFPB - Universidade Federal da \\ Paraíba, João Pessoa, Brazil \\ ${ }^{3}$ Department of Clinic and Social \\ Dentistry, UFPB - Universidade Federal \\ da Paraíba, João Pessoa, Brazil \\ ${ }^{4}$ Department of Statistics, \\ UFPB - Universidade Federal da \\ Paraíba, João Pessoa, Brazil
}

Correspondence: 1sabella Lima Arrais Ribeiro, Av. Bandeirantes, 3900, 14049-900 Ribeirão Preto, SP, Brasil. Tel: +55-83-98815-5055. e-mail- isabella_arrais@yahoo.com

Key Words: oral mucositis, cancer, pediatric, oncology, chemotherapy.

\section{Introduction}

Oral mucositis is the most common oral problem presented by pediatric oncology patients after starting antineoplastic treatment with chemotherapeutic agents, being one of the main adverse effects of the chemotherapy (1-5). This oral condition is described as inflammatory lesions and/or painful ulcerations, with or without pseudomembrane. Its severity is influenced by the variables associated to patients and by the antineoplastic treatment and its pathophysiology is composed by four interdependent phases: 1. inflammatory/vascular phase; 2. epithelial phase; 3 . ulcerative/bacteriological phase and 4. repair phase (6). The concern about this condition is in reason of the ulcerations (condition considered as Severe oral mucositis-SOM) in oral mucosa cause severe pain, difficult or impossibility for nutrition maintenance for oral feeding, besides more susceptibility to local and systemic infections, and important reduction in quality of life (1-7). In addition, the SOM has been the major cause of discontinuation of antineoplastic treatment, causing delays and even breaks in therapy, resulting in worsening of overall prognosis related to cure of cancer (2).

Oral mucositis is associated with chemotherapeutic agents that act against to neoplastic cells without differentiating normal cells and affecting specially tissues that renewed more frequently, as the oral mucosa (13). It occurs mainly on young individuals, and, for this reason, previous studies have shown that young patients are at greater risk of chemotherapy affecting their oral health (5-9).

The mechanism of action of chemotherapeutic agents is related to preventing cellular replication, either by blocking DNA synthesis (Antimetabolites agents) (10); making a cellular alkylating effect, preventing the cellular division (Alkylating agents) (11); interfering with the production of proteins important for cellular division (Natural Products) (12); or structurally, distorting DNA, altering the cellular functions (Miscellaneous) (13). It is known that chemotherapeutic agents are not equally stomatotoxic and some can induce oral mucositis more than others $(1,5,6)$.

Chemo-induced oral mucositis, particularly the severe form, is characterized by ulcerations in oral mucosa and its occurrence is multifactorial. These factors could include age, type of cancer, systemic conditions, chemotherapeutic agents, and frequency of drug administration $(14,15)$. 
Despite of previous published papers focusing chemoinduced severe oral mucositis emergence, statistical models with global associate variables is desirable, but poorly explored and few employed, especially statistical models that represent the study of variables involved in appearance of severe oral mucositis prospectively after initiated the chemotherapeutic treatment, and that evaluate the models separately, for patients with hematologic and solid tumors $(2,4,15)$.

Based on this information and perceived needs in the world literature about the subject, we conducted this study to evaluate the factors associated with the occurrence of severe oral mucositis (SOM) in pediatric oncology patients during the chemotherapeutic treatment.

\section{Material and Methods}

This is a prospective and observational study by a nested case-control to a cohort study; with inductive approach, rigorous direct observation and comparative statistical procedures.

This study was conducted in the pediatric sector in a Hospital in João Pessoa, state of Paraiba, Northeast of Brazil, a reference center for the prevention, diagnosis, and treatment of cancer.

Between April 2013 and July 2015, the patients selected were assisted by the Pediatric Oncology sector of the Hospital, diagnosed and treated for some type of malignancy, and met the following inclusion criteria: aged between 0 and 19 years; did not start the antineoplastic treatment; have prevision for received chemotherapeutic treatment alone for the first few months; did not have inflammation of the oral mucosa before the start of chemotherapeutic treatment; and the caregiver gave consent for the child/adolescent to participate in the study.

A total of 115 patients were included, and 105 children/ adolescents were monitored until the end of the study. The losses in the different follow-up intervals occurred for the following reasons: between the first and fourth week, 1 patient died; between the fifth and seventh weeks, 2 patients were transferred to another hospital, and 2 patients died; in the eighth week, 1 patient started radiotherapy in the head and neck regions, and 2 patients died; and in the ninth week, 2 patients died.

The variables of interest were chosen based on scientific literature that have studied the variables involved with oral mucositis (4-15) and were included other variables that we had interest in to evaluate as risk factors, especially in the multivariate model. Thus, the variables of interest in this study were: sex, age, ethnicity, type of disease (hematologic or solid tumors, blood group (all collected at diagnosis), period since the last chemotherapy, class of chemotherapeutic drugs
(Antimetabolites agents=methotrexate, 5-fluorouracil, cytarabine, mercaptopurine, among others; Alkylating agents=ciclofosfamide, ifosfamide, dacarbazine, among others; Natural Products=vincristine, vimblastine, etoposide, topotecan, daunorrubicin, L-asparaginase, among others; Miscellaneous=cisplatin, carboplatin, procarbazine, imatinib, among others), frequency of chemotherapy doses, leukocytes and platelets counts and creatinine blood level (all collected for 10 consecutive weeks after the start of chemotherapeutic treatment. The demographic, clinical and laboratory data were evaluated from the medical records. The outcome (Severe oral mucositis-SOM) was collected in each of the 10 weeks of evaluation using the modified Oral Assessment Guide $(O A G)$ by a researcher calibrated (kappa $>0.85)(5)$.

The patients were divided into case and control groups within the prospective cohort according the presence or absence of Severe oral mucositis in each week of clinical evaluation.

During the follow-up of this study all the patients and caregivers were clinically evaluated weekly and instructed to rigorous oral hygiene care. When oral mucositis was diagnosed in any phase (mild, moderate or severe, according to $O A G)$, low-level laser therapy was performed according to the protocol: calibrated for a wavelength of $670 \mathrm{~nm}$, power of $40 \mathrm{~mW}$, and dose of $4 \mathrm{~J} / \mathrm{cm} 2$, applied locally for $30 \mathrm{~s}$ on reddish, erosive and/ or ulcerated regions. Thus, all the patients received oral health surveillance and were treated to oral mucositis and to other oral problems. For this reason, this factor was controlled and the variables "oral hygiene", "dental treatments" and "treatment of oral mucositis" were not included in the statistical analysis with the other variables.

Data were analysed using descriptive and inferential statistics by logistic regression using $\mathrm{R}$ software version 3.1.3 (Bell Laboratories).

It was decided to group OAG scores 1 and 2 into a nominal category designated "without SOM", which received the code 0 in the database; and the score 3 into another nominal category designated "with SOM", which received the code 1 in the database; the latter was the outcome of interest, and therefore, the outcome was dichotomized. By adopting this criterion, whenever one or more sites in the oral cavity evaluated by the OAG were given a score of 3, the patient's oral mucositis status was characterized as "with SOM" because of the occurrence of ulceration in one or more sites, making the clinical status more serious than those of other conditions evaluated by the OAG. We adjusted models for each of the groups of malignancies, a model for patients with hematologic neoplasms and other for patients with solid tumors.

Initially, univariate analysis was conducted by binary 
logistic regression of the outcome of interest and each variable of interest, adopting a significance level of 30\% to select the largest possible number of variables in the multiple regression analysis. After completing the multiple binary logistic regression analysis using the backward method, the models were adjusted for each week of follow-up, adopting a significance level of 5\% for the adjusted final models.

All procedures performed in this study were in accordance with the ethical standards of the institutional and national research committee and with the 1964 Helsinki declaration and its later amendments or comparable ethical standards. This study was approved by the Ethics Committee on Human Research under Presentation Certificate for Ethics Assessment number 12922113.8.0000.5188 and all the patients gave informed consent to be included in this study. Informed consent was obtained from all individual participants included in the study.

\section{Results}

We followed 105 patients during the 10-week followup, being $54.30 \%$ male. In hematologic neoplasms group, the female sex was predominant $(n=28 ; 51.90 \%)$ and in solid tumor group, the male sex was predominant $(n=31$; $60.80 \%)$.

The mean age for all patients was about $7.30 \pm 5.17$ years old, with minimum and maximum values of 0 and 18 years old, respectively. For patients with hematologic neoplasms $(n=54)$, the mean age was $6.83 \pm 5.00$, a minimum of 2 and maximum of 18 years old; and for patients with solid tumors $(n=51)$, the mean age was $7.80 \pm 5.83$ years old, with minimum of 0 and maximum of 18 years old.

The highest concentrations of the neoplastic cases were observed in patients with 2 years old $(n=18 ; 17.0 \%), 4$ years old $(n=16 ; 15.20 \%)$, and 3 years old $(n=10 ; 9.50 \%)$. In the hematologic neoplasms group, the age with more concentration of cases was 4 years old $(n=12 ; 22.20 \%)$ and the solid tumors group was 2 years old, with 11 $(21.60 \%)$ cases.

The mixed ethnicity predominated compared with the other ethnicities, corresponding to $50(47.50 \%)$ cases, followed by white $(n=32 ; 30.6 \%)$, black $(n=22$; $21.00 \%)$, and indigenous $(\mathrm{n}=1 ; 0.90 \%)$ ethnicities. In both patient groups (hematologic neoplasms and solid tumors) prevailed patients with mixed ethnicity, corresponding to $50.00 \%$ and $45.10 \%$, respectively.

In hematologic neoplasms group, the highest prevalence was Acute Lymphoid Leukemia $(n=42 ; 77.80 \%)$, followed by Non-Hodgkin Lymphoma $(n=8 ; 14.80 \%)$, Acute Myeloid Leukemia $(n=3 ; 5.60 \%)$ and Hodgkin
Lymphoma $(n=1 ; 1.90 \%)$. In solid tumors group the highest prevalence was Wilms's tumor $(n=18 ; 35.30 \%)$, followed by Osteosarcoma ( $n=13 ; 25.50 \%)$, Embryonal Rhabdomyosarcoma $(n=5 ; 9.8 \%)$, Adenocarcinoma $(n=4$; $7.80 \%)$, Neuroblastoma $(n=3 ; 5.90 \%)$, and, with few cases, Germinative cells and Brain tumors $(n=2 ; 3.90 \%$, each); and Melanoma, Lymphoepithelioma, Alveolar Sarcoma and Synovial Sarcoma ( $n=1 ; 2.00 \%$, each).

Regarding the $\mathrm{ABO}$ blood groups, 53 patients $(50.60 \%)$ were type $A_{1} 41(39.00 \%)$ were type $0,10(9.50 \%)$ were type $B$, and $1(0.90 \%)$ was type $A B$. Additionally, 92 $(87.60 \%)$ patients were positive for Rh factor, and 13 $(12.40 \%)$ were negative. Both the groups, patients with hematologic neoplasms and solid tumors, the blood of A type was prevalent, with $30(58.80 \%)$ and $23(42.60 \%)$ patients, respectively.

The distribution of the Severe oral mucositis for each study group (hematologic and solid tumors) can be observed in Table 1 and for the ten weeks of evaluation there was not difference between the groups for the distribution of SOM ( $p$-value $>0,05$ ).

The distribution of the classes of chemotherapeutic agents administrated to the patients and the means (and

Table 1. Distribution of severe oral mucositis in the groups of tumors, hematologic $(n=54)$ and solid $(n=51)$, for the 10 weeks of evaluation. João Pessoa, Paraíba, Brazil. 2017

\begin{tabular}{|c|c|c|c|c|}
\hline $\begin{array}{l}\text { Treatment } \\
\text { week }\end{array}$ & $\begin{array}{l}\text { Severe oral } \\
\text { mucositis }\end{array}$ & $\begin{array}{c}\text { Hematologic } \\
\text { tumors }\end{array}$ & Solid tumors & $\mathrm{p}$-value \\
\hline \multirow{2}{*}{$1^{\text {st }}$} & Yes & $9(47.40 \%)$ & $10(52.60 \%)$ & \multirow{2}{*}{0.696} \\
\hline & No & $45(52.30 \%)$ & $41(47.70 \%)$ & \\
\hline \multirow{2}{*}{$2^{\text {nd }}$} & Yes & $19(57.60 \%)$ & $14(42.40 \%)$ & \multirow{2}{*}{0.394} \\
\hline & No & 35 (48.60\%) & 37 (51.40\%) & \\
\hline \multirow{2}{*}{$3^{\text {rd }}$} & Yes & $18(62.10 \%)$ & $11(37.90 \%)$ & \multirow{2}{*}{0.178} \\
\hline & No & $36(47.40 \%)$ & $40(52.60 \%)$ & \\
\hline \multirow{2}{*}{$4^{\text {th }}$} & Yes & $16(59.30 \%)$ & $11(40.70 \%)$ & \multirow{2}{*}{0.345} \\
\hline & No & $38(48.70 \%)$ & $40(51.30 \%)$ & \\
\hline \multirow{2}{*}{$5^{\text {th }}$} & Yes & $10(47.60 \%)$ & $11(52.40 \%)$ & \multirow{2}{*}{0.696} \\
\hline & No & $44(52.40 \%)$ & $40(47.60 \%)$ & \\
\hline \multirow{2}{*}{$6^{\text {th }}$} & Yes & $19(61.30 \%)$ & $12(38.70 \%)$ & \multirow{2}{*}{0.191} \\
\hline & No & $35(47.30 \%)$ & $39(52.70 \%)$ & \\
\hline \multirow{2}{*}{$7^{\text {th }}$} & Yes & $10(45.50 \%)$ & $12(54.50 \%)$ & \multirow{2}{*}{0.528} \\
\hline & No & $44(53.00 \%)$ & $39(47.00 \%)$ & \\
\hline \multirow{2}{*}{$8^{\text {th }}$} & Yes & $16(48.50 \%)$ & $17(51.50 \%)$ & \multirow{2}{*}{0.683} \\
\hline & No & $38(52.80 \%)$ & $34(47.20 \%)$ & \\
\hline \multirow{2}{*}{$9^{\text {th }}$} & Yes & $10(58.80 \%)$ & 7 (41.20\%) & \multirow{2}{*}{0.505} \\
\hline & No & $44(50.00 \%)$ & $44(50.00 \%)$ & \\
\hline \multirow{2}{*}{$10^{\text {th }}$} & Yes & $11(64.70 \%)$ & $6(35.30 \%)$ & \multirow{2}{*}{0.232} \\
\hline & No & $43(48.90 \%)$ & 45 (51.10\%) & \\
\hline
\end{tabular}

Qui-Square test; level of significance $=5 \%$. 
standard deviation), minimum and maximum to frequency of administration of chemotherapy doses for the 10 weeks of evaluation, in the groups of tumors, hematologic and solid are demonstrate in Tables 2 and 3, respectively.

The results of the logistic regression for each of evaluation week are shown in the Table 4 (for group of patients with hematologic tumors) and Table 5 (for group of patients with solid tumors).

For the pediatric patients with hematologic tumors were found factors associated to SOM in the 6 th (increase in frequency of chemotherapy doses $(\mathrm{OR}=3.02))$ and in the 7 th (female sex $(O R=21.28)$ and increase in frequency of chemotherapy doses $(\mathrm{OR}=2.51)$ ) weeks of evaluation (Table 4). In this group of the patients, was possible to observe that the frequency of administration of chemotherapy doses had more influence than the chemotherapeutic agents besides representing a risk factor also the female sex compared to the male.

It was possible found factors associated to SOM in five weeks of treatment for the group of patients with solid tumors: in the $1^{\text {st }}$ (female $\operatorname{sex}(O R=14.43)$, and age increase (1.24)); $2^{\text {nd }}$ (Miscellany $\left.(\mathrm{OR}=6.39)\right) ; 5^{\text {th }}$ (Antimetabolites ( $\mathrm{OR}=17.44)$, Miscellany ( $\mathrm{OR}=45.42)$, and platelets reduction $(\mathrm{OR}=1.12)$ ); $6^{\text {th }}$ (creatinine increase $(O R=1.63)) ;$ and in the $7^{\text {th }}$ (creatinine increase $(O R=2.39)$ ) weeks of follow-up (Table 5). As way, it is observed that the female sex presented a risk of 14.43 times higher than the male in the $1^{\text {st }}$ week, as well as the increase in the age (each every one year of increase in age, the chance of SOM occurrence is increased in 1.24 times). From the $2^{\text {nd }}$ week of treatment, the chemotherapeutic agents (Miscellany and Antimetabolites) and the increase in blood level of creatinine constituted risk factors to SOM in patients with solid tumors.

\section{Discussion}

To the best of our knowledge, this is the first study to identify the factors associated with the occurrence of SOM in children and adolescents undergoing chemotherapy over a 10-week follow-up by developing statistical models to identify factors involved for the emergence of these lesions individualizing the group of patients with hematologic neoplasms and solid tumors. The time period in which this study was performed goes beyond the other studies already published and the follow-up period corresponds to the phase of treatment in which the chemotherapy is instituted at a higher dose and frequency to control tumor growth, especially in children and adolescents, in reason of the diagnosis occurs lately and there is a need to control tumor growth to increase the chances of cure $(1-5,7,8)$. In addition, the present study evaluated jointly, to each week of treatment, several
Table 2. Distribution of the classes of chemotherapeutic agents administrated to patients in each of 10 weeks of evaluation, in the groups of tumors, hematologic $(n=54)$ and solid $(n=51)$. João Pessoa, Paraíba, Brazil. 2017

\begin{tabular}{|c|c|c|c|}
\hline \multirow{2}{*}{$\begin{array}{l}\text { Treatment } \\
\text { Week }\end{array}$} & \multirow{2}{*}{$\begin{array}{c}\text { Class of } \\
\text { chemotherapeutic } \\
\text { agents }\end{array}$} & \multicolumn{2}{|c|}{ Tumor group } \\
\hline & & $\begin{array}{c}\text { Hematologic } \\
n(\%)\end{array}$ & Solid n (\%) \\
\hline \multirow{4}{*}{$1^{\text {st }}$} & Alkylating agents & $5(9.30 \%)$ & $16(31.40 \%)$ \\
\hline & Antimetabolites & $33(61.20 \%)$ & $9(17.60 \%)$ \\
\hline & Natural products & $13(24.10 \%)$ & $25(49.00 \%)$ \\
\hline & Miscellaneous & $3(5.60 \%)$ & $1(2.00 \%)$ \\
\hline \multirow{4}{*}{$2^{\text {nd }}$} & Alkylating agents & $1(1.90 \%)$ & $13(25.50 \%)$ \\
\hline & Antimetabolites & $38(70.40 \%)$ & $9(17.60 \%)$ \\
\hline & Natural products & $13(24.10 \%)$ & $31(60.80 \%)$ \\
\hline & Miscellaneous & $3(5.60 \%)$ & $4(7.90 \%)$ \\
\hline \multirow{4}{*}{$3^{\text {rd }}$} & Alkylating agents & $4(7.40 \%)$ & $11(21.60 \%)$ \\
\hline & Antimetabolites & $33(61.20 \%)$ & $10(19.60 \%)$ \\
\hline & Natural products & $14(25.80 \%)$ & $33(64.70 \%)$ \\
\hline & Miscellaneous & $3(5.60 \%)$ & $0(0.00 \%)$ \\
\hline \multirow{4}{*}{$4^{\text {th }}$} & Alkylating agents & $2(3.70 \%)$ & $9(17.70 \%)$ \\
\hline & Antimetabolites & $40(74.10 \%)$ & $10(19.60 \%)$ \\
\hline & Natural products & $10(18.60 \%)$ & $35(68.60 \%)$ \\
\hline & Miscellaneous & $3(5.60 \%)$ & $3(5.90 \%)$ \\
\hline \multirow{4}{*}{$5^{\text {th }}$} & Alkylating agents & $3(5.60 \%)$ & $9(17.70 \%)$ \\
\hline & Antimetabolites & $44(81.50 \%)$ & $11(21.60 \%)$ \\
\hline & Natural products & $4(7.40 \%)$ & $34(66.70 \%)$ \\
\hline & Miscellaneous & $3(5.60 \%)$ & $3(5.90 \%)$ \\
\hline \multirow{4}{*}{$6^{\text {th }}$} & Alkylating agents & $1(1.90 \%)$ & $12(23.50 \%)$ \\
\hline & Antimetabolites & $2(3.70 \%)$ & $9(17.60 \%)$ \\
\hline & Natural products & $11(20.40 \%)$ & $33(64.70 \%)$ \\
\hline & Miscellaneous & $3(5.60 \%)$ & $3(5.90 \%)$ \\
\hline \multirow{4}{*}{$7^{\text {th }}$} & Alkylating agents & $2(3.70 \%)$ & $10(19.60 \%)$ \\
\hline & Antimetabolites & $44(81.50 \%)$ & $10(19.60 \%)$ \\
\hline & Natural products & $5(9.30 \%)$ & $34(66.70 \%)$ \\
\hline & Miscellaneous & $3(5.60 \%)$ & $3(5.90 \%)$ \\
\hline \multirow{4}{*}{$8^{\text {th }}$} & Alkylating agents & $1(1.90 \%)$ & $10(19.60 \%)$ \\
\hline & Antimetabolites & 47 (87.10\%) & $10(19.60 \%)$ \\
\hline & Natural products & $5(9.30 \%)$ & $34(66.70 \%)$ \\
\hline & Miscellaneous & $3(5.60 \%)$ & $3(5.90 \%)$ \\
\hline \multirow{4}{*}{$9^{\text {th }}$} & Alkylating agents & $5(9.30 \%)$ & $9(17.60 \%)$ \\
\hline & Antimetabolites & $42(77.80 \%)$ & $9(17.60 \%)$ \\
\hline & Natural products & $6(11.20 \%)$ & $35(68.60 \%)$ \\
\hline & Miscellaneous & $3(5.60 \%)$ & $4(7.90 \%)$ \\
\hline \multirow{4}{*}{$10^{\text {th }}$} & Alkylating agents & $3(5.60 \%)$ & $10(19.60 \%)$ \\
\hline & Antimetabolites & $43(79.50 \%)$ & $10(19.60 \%)$ \\
\hline & Natural products & $5(9.30 \%)$ & $34(66.70 \%)$ \\
\hline & Miscellaneous & $3(5.60 \%)$ & 3 (5.90\%) \\
\hline
\end{tabular}

The sum of the percentual frequencies may result in more than $100.00 \%$ because in some weeks the same patient made use of more than one type of chemotherapeutic class. 
variables correlated with the occurrence of SOM, since the risk related to chemotherapy may be potentiated by other factors, such as the sex, the age, the alterations in blood components, the frequency of chemotherapy administration and changes in creatinine blood level.

The outcome was determined considering that in the Oral Assessment Guide (5), a condition receiving a score of 3 (Severe oral mucositis) could cause major impairments in speech and swallowing and exposure to local and systemic infections, which could significantly change the quality of life and compromise the progress of antineoplastic therapy, which might need to be interrupted to establish antibiotic therapy to contain the infection (1-9).

All patients followed in this study were evaluated weekly for oral mucositis according to the OAG and, in case of minimal inflammation diagnosed in the oral mucosa, the laser therapy was performed according to the protocol described in the methods section. Likewise, all other problems diagnosed in the oral cavity were

Table 3. Distribution of means to frequency of administration of chemotherapy doses for the 10 weeks of evaluation, in the groups of tumors, hematologic $(n=54)$ and

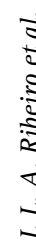

solid (n=51). João Pessoa, Paraíba, Brazil. 2017

\begin{tabular}{|c|c|c|c|c|}
\hline $\begin{array}{l}\text { Treatment } \\
\text { week }\end{array}$ & Tumor group & Mean (SD) & Minimum & Maximum \\
\hline \multirow{2}{*}{$1^{\text {st }}$} & Hematologic & $1.39(0.92)$ & $1(\mathrm{n}=45 ; 83.30 \%)$ & $4(\mathrm{n}=4 ; 7.40 \%)$ \\
\hline & Solid & 1.59 (1.09) & $1(\mathrm{n}=36 ; 70.60 \%)$ & $5(\mathrm{n}=2 ; 3.90 \%)$ \\
\hline \multirow{2}{*}{$2^{\text {nd }}$} & Hematologic & $1.43(1.03)$ & $1(\mathrm{n}=45 ; 83.30 \%)$ & $5(\mathrm{n}=2 ; 3.70 \%)$ \\
\hline & Solid & $1.69(1.34)$ & $1(\mathrm{n}=39 ; 76.50 \%)$ & $5(\mathrm{n}=4 ; 7.80 \%)$ \\
\hline \multirow{2}{*}{$3^{\text {rd }}$} & Hematologic & $1.48(1.07)$ & $1(\mathrm{n}=44 ; 81.50 \%)$ & $5(\mathrm{n}=1 ; 1.90 \%)$ \\
\hline & Solid & $2.00(2.24)$ & $1(\mathrm{n}=39 ; 76.50 \%)$ & $9(\mathrm{n}=3 ; 5.90 \%)$ \\
\hline \multirow{2}{*}{$4^{\text {th }}$} & Hematologic & $1.56(1.12)$ & $1(\mathrm{n}=42 ; 77.80 \%)$ & $5(\mathrm{n}=1 ; 1.90 \%)$ \\
\hline & Solid & $2.04(2.30)$ & $1(\mathrm{n}=40 ; 78.40 \%)$ & $9(\mathrm{n}=3 ; 5.90 \%)$ \\
\hline \multirow{2}{*}{$5^{\text {th }}$} & Hematologic & $1.74(1.21)$ & $1(\mathrm{n}=37 ; 68.50 \%)$ & $5(\mathrm{n}=1 ; 1.90 \%)$ \\
\hline & Solid & $1.80(2.05)$ & $1(\mathrm{n}=41 ; 80.40 \%)$ & $9(\mathrm{n}=3 ; 5.90 \%)$ \\
\hline \multirow{2}{*}{$6^{\text {th }}$} & Hematologic & $2.09(1.41)$ & $1(\mathrm{n}=32 ; 59.30 \%)$ & $5(\mathrm{n}=2 ; 3.70 \%)$ \\
\hline & Solid & $2.18(2.24)$ & $1(\mathrm{n}=34 ; 66.70 \%)$ & $9(\mathrm{n}=3 ; 5.90 \%)$ \\
\hline \multirow{2}{*}{$7^{\text {th }}$} & Hematologic & $2.20(1.76)$ & $1(\mathrm{n}=33 ; 61.10 \%)$ & $8(\mathrm{n}=2 ; 3.70 \%)$ \\
\hline & Solid & $2.06(2.15)$ & $1(\mathrm{n}=35 ; 68.60 \%)$ & $9(\mathrm{n}=3 ; 5.90 \%)$ \\
\hline \multirow{2}{*}{$8^{\text {th }}$} & Hematologic & $1.78(1.25)$ & $1(\mathrm{n}=38 ; 70.40 \%)$ & $4(\mathrm{n}=11 ; 20.40 \%)$ \\
\hline & Solid & $1.98(2.08)$ & $1(\mathrm{n}=36 ; 70.60 \%)$ & $9(\mathrm{n}=3 ; 5.90 \%)$ \\
\hline \multirow{2}{*}{$9^{\text {th }}$} & Hematologic & $1.76(1.28)$ & $1(\mathrm{n}=39 ; 72.20 \%)$ & $5(\mathrm{n}=2 ; 3.70 \%)$ \\
\hline & Solid & $1.55(1.30)$ & $1(\mathrm{n}=40 ; 78.40 \%)$ & $8(\mathrm{n}=1 ; 2.00 \%)$ \\
\hline \multirow{2}{*}{$10^{\text {th }}$} & Hematologic & $1.89(1.43)$ & $1(\mathrm{n}=37 ; 68.50 \%)$ & $6(\mathrm{n}=2 ; 3.70 \%)$ \\
\hline & Solid & $1.84(2.01)$ & $1(\mathrm{n}=39 ; 76.50 \%)$ & $9(\mathrm{n}=3 ; 5.90 \%)$ \\
\hline
\end{tabular}

$\mathrm{SD}=$ Standard deviation treated similarly in both study groups and the oral hygiene conditions were evaluated and the patients and your caregivers were instructed weekly to perform rigorous oral hygiene each time they ate, upon waking up and before bedtime. Thus, factors related to oral hygiene, dental treatments and interventions in oral mucositis were controlled and not evaluated in the statistical models. Oral health surveillance is essential to the proper course of antineoplastic treatment, especially in its onset $(1,5)$. The intervention, as soon as oral mucositis is diagnosed, regardless of its stage, is essential to prevent worsening of the condition. Attention and intervention as soon as oral problems are perceived contribute to do not be necessary to interrupt the antineoplastic treatment to treat oral mucositis and other problems, so oral health surveillance for these patients is a way to prevent oral disorders and interruptions in antineoplastic therapy.

The age groups with the greatest impairment by neoplasms corroborate the results of Nascimento et al. (15), and the mean age found in the present study was similar to the mean age reported by Cheng et al. (14) for 102 patients (7.6 years). Greater impairment among males was also observed in other studies $(4,14,16)$. In this study, in hematologic neoplasms group, the female was slightly predominant and in group of solid tumors, the male was predominant. Among hematologic diseases, Acute Lymphoblastic Leukemia is the underlying disease with the highest predominance among children and adolescents $(4,15,17)$.

The mean duration of the tumor remissioninduction phase under a chemotherapy regimen is 1.0 to 2.5 months, and in general, after this period, other treatments, such as radiation therapy and surgery, are combined with chemotherapy (18). In addition, the main complications of oral mucositis usually appear during this initial period of treatment $(5,8)$. For these reasons, the evaluations were conducted in the first 10 weeks of treatment, with a mean duration of 2.5 months, to assess when SOM occurred.

Previous studies have not estimated the risk for SOM for the different sexes $(14,15)$, and associations between the occurrence of SOM and the male sex are rare (19). Meeske et al. (20) evaluated the toxicity of chemotherapy in the first four phases of therapy in children treated for high-risk Acute Lymphoblastic Leukemia and observed that female patients had higher levels of 
gastrointestinal toxicity associated with chemotherapy, required greater use of antibiotics, had longer hospital stays, and showed a 2.8-fold higher risk of death from chemotherapy-related causes compared with male patients. These results are consistent with those of the present study because of the high stomatotoxicity associated with the female sex both patients, with hematologic and solid tumors.

The analysis developed for the solid tumors group indicated that the treatment with Miscellaneous and Antimetabolites constituted risk factors for SOM in $2^{\text {nd }}$ and $5^{\text {th }}$ weeks, respectively. The

Table 4. Univariate and multiple analysis for occurrence of severe oral mucositis in pediatric patients with hematologic tumors ( $\mathrm{n}=54)$. João Pessoa, Paraíba, Brazil. 2017

\begin{tabular}{|c|c|c|c|c|c|}
\hline \multirow{2}{*}{$\begin{array}{l}\text { Treatment } \\
\text { week }\end{array}$} & \multicolumn{2}{|c|}{ Univariate analysis } & \multicolumn{2}{|c|}{ Multiple analysis } & \multirow{2}{*}{ Reference category } \\
\hline & Variable & p-value & OR [CI 95\%] & p-value & \\
\hline \multirow{3}{*}{$1^{\text {st }}$} & Skin Color & 0.084 & & & $\begin{array}{l}\text { (white, mixed, } \\
\text { and indigenous) }\end{array}$ \\
\hline & Antimetabolites & 0.092 & & & $\begin{array}{l}\text { Not having been } \\
\text { treated with this } \\
\text { drug type }\end{array}$ \\
\hline & Leukocytes e & 0.127 & & & \\
\hline \multirow[t]{2}{*}{$2^{\text {nd }}$} & Skin Color & 0.286 & & & $\begin{array}{l}\text { white, mixed, and } \\
\text { indigenous) }\end{array}$ \\
\hline & Platelets ${ }^{\mathrm{f}}$ & 0.210 & & & \\
\hline \multirow{7}{*}{$3^{\text {rd }}$} & Skin Color & 0.236 & & & $\begin{array}{l}\text { (white, mixed, } \\
\text { and indigenous) }\end{array}$ \\
\hline & Age $\mathrm{a}^{\mathrm{a}}$ & 0.158 & & & \\
\hline & Blood Group & 0.137 & & & $\begin{array}{l}\text { Blood groups } \\
(\mathrm{A}, \mathrm{AB}, \mathrm{O})\end{array}$ \\
\hline & Platelets ${ }^{\mathrm{f}}$ & 0.090 & & & \\
\hline & Creatinine $^{\mathrm{d}}$ & 0.088 & & & \\
\hline & Natural Products & 0.071 & & & $\begin{array}{l}\text { Not having been } \\
\text { treated with this } \\
\text { drug type }\end{array}$ \\
\hline & Leukocytes e & 0.211 & & & \\
\hline \multirow[t]{2}{*}{$4^{\text {th }}$} & $\begin{array}{l}\text { Time since last } \\
\text { chemotherapy }{ }^{\mathrm{b}}\end{array}$ & 0.158 & & & \\
\hline & Creatinine $^{\mathrm{d}}$ & 0.115 & & & \\
\hline \multirow{3}{*}{$5^{\text {th }}$} & Sex (Female) & 0.281 & & & Sex (Male) \\
\hline & Age $^{a}$ & 0.304 & & & \\
\hline & $\begin{array}{l}\text { Time since last } \\
\text { chemotherapy }{ }^{\mathrm{b}}\end{array}$ & 0.302 & & & \\
\hline \multirow{7}{*}{$6^{\text {th }}$} & Age $^{a}$ & 0.063 & & & \\
\hline & $\begin{array}{l}\text { Time since last } \\
\text { chemotherapy }{ }^{b}\end{array}$ & 0.126 & & & \\
\hline & Antimetabolites & 0.049 & & & $\begin{array}{l}\text { Not having been } \\
\text { treated with this } \\
\text { drug type }\end{array}$ \\
\hline & $\begin{array}{c}\text { Frequency of } \\
\text { chemotherapy doses }{ }^{c}\end{array}$ & 0.000 & $3.02[5.12-1.78]$ & $\mathrm{p}<0.001$ & \\
\hline & Leukocytes e & 0.129 & & & \\
\hline & Platelets $\mathrm{f}$ & 0.187 & & & \\
\hline & Creatinine $^{\mathrm{d}}$ & 0.088 & & & \\
\hline
\end{tabular}


Miscellaneous agents can be related to great cytotoxicity in reason of alterations promoted in the normal cell functions (13). In $2^{\text {nd }}$ week, a higher frequency of patients used this class of drugs compared to the other weeks, where the same frequency only repeats in the $9^{\text {th }}$ week of treatment. In the first weeks of treatment, the chemotherapy doses need to be higher to observe the expected effect on the reduction of solid tumor size and to predict the prognosis of the tumor response to chemotherapy $(10,15,16)$. In the $2^{\text {nd }}$ week Miscellaneous was considered as an isolated risk factor, but, in the $5^{\text {th }}$ week, the effect of Miscellaneous and Antimetabolites were enhanced by the increase in

Table 4. Univariate and multiple analysis for occurrence of severe oral mucositis in pediatric patients with hematologic tumors ( $\mathrm{n}=54)$. João Pessoa, Paraíba, Brazil. 2017 (cont.)

\begin{tabular}{|c|c|c|c|c|c|}
\hline \multirow{2}{*}{$\begin{array}{l}\text { Treatment } \\
\text { week }\end{array}$} & \multicolumn{2}{|c|}{ Univariate analysis } & \multicolumn{2}{|c|}{ Multiple analysis } & \multirow{2}{*}{ Reference category } \\
\hline & Variable & $\mathrm{p}$-value & OR [CI 95\%] & p-value & \\
\hline \multirow{5}{*}{$7^{\text {th }}$} & Sex & 0.019 & 21.28 [38.35-11.81] & 0.048 & Sex (Male) \\
\hline & Age $^{a}$ & 0.095 & & & \\
\hline & $\begin{array}{c}\text { Frequency of } \\
\text { chemotherapy doses }\end{array}$ & 0.039 & $2.51[5.27-1.20]$ & 0.014 & \\
\hline & Leukocytes ${ }^{\mathrm{e}}$ & 0.209 & & & \\
\hline & Platelets ${ }^{f}$ & 0.162 & & & \\
\hline \multirow{5}{*}{$8^{\text {th }}$} & Sex (Female) & 0.219 & & & Sex (Male) \\
\hline & $\begin{array}{l}\text { Time since last } \\
\text { chemotherapy }^{\mathrm{b}}\end{array}$ & 0.092 & & & \\
\hline & $\begin{array}{c}\text { Frequency of } \\
\text { chemotherapy doses }\end{array}$ & 0.164 & & & \\
\hline & Leukocytes ${ }^{\mathrm{e}}$ & 0.228 & & & \\
\hline & Creatinine $^{\mathrm{d}}$ & 0.278 & & & \\
\hline \multirow{3}{*}{$9^{\text {th }}$} & Sex (Female) & 0.281 & & & Sex (Male) \\
\hline & $\begin{array}{l}\text { Time since last } \\
\text { chemotherapy }^{\mathrm{b}}\end{array}$ & 0.856 & & & \\
\hline & $\begin{array}{c}\text { Frequency of } \\
\text { chemotherapy doses }\end{array}$ & 0.126 & & & \\
\hline \multirow{5}{*}{$10^{\text {th }}$} & Sex (Female) & 0.281 & & & Sex (Male) \\
\hline & Time $^{b}$ & 0.131 & & & \\
\hline & Natural Products & 0.299 & & & $\begin{array}{l}\text { Not having been } \\
\text { treated with this } \\
\text { drug type }\end{array}$ \\
\hline & Leukocytes e & 0.182 & & & \\
\hline & Creatinine $^{f}$ & 0.295 & & & \\
\hline
\end{tabular}

$a=$ For each increase of 1-year; $b=$ For each increase of 1-day; $c=$ For each increase of 1-dose; $d=$ For each increase of 0.1-unit in the blood concentration; e=For each reduction of 1,000-leukocytes; $f=$ For each reduction of 10,000-platelets. $\mathrm{OR}=0 \mathrm{dds}$ Ratio; $\mathrm{CI}=$ Confidence Interval. The increase or the reduction in blood components were evaluated considering the normal parameters for pediatric patients. 
blood level of creatinine. Some authors reported that the Miscellaneous and Antimetabolites agents are the chemotherapeutic drugs most strongly associated with stomatotoxicity and, consequently, with Severe oral mucositis $(1,3,13,21)$.

In the $6^{\text {th }}$ week of evaluation, in the solid tumors group, the blood level increase of creatinine was a risk factor. This result is similar to the other study that identified it as a risk factor for the onset of Severe oral mucositis (22). Ip et al. (16) did not find an association between the blood levels of creatinine and the presence of Moderate to Severe oral mucositis during the initial period of chemotherapy. This increase was expected in blood creatinine, which previous studies have identified as a risk factor; this increase has also been shown to enhance the cytotoxicity of anticancer drugs (23-25).

Table 5. Univariate and multiple analysis for occurrence of severe oral mucositis in pediatric patients with solid tumors ( $\mathrm{n}=51)$. João Pessoa, Paraíba, Brazil, 2017

\begin{tabular}{|c|c|c|c|c|c|}
\hline \multirow{2}{*}{$\begin{array}{l}\text { Treatment } \\
\text { week }\end{array}$} & \multicolumn{2}{|c|}{ Univariate analysis } & \multicolumn{2}{|c|}{ Multiple analysis } & \multirow{2}{*}{$\begin{array}{l}\text { Reference } \\
\text { category }\end{array}$} \\
\hline & Variable & p-value & OR [CI95\%] & p-value & \\
\hline \multirow{8}{*}{$1^{\text {st }}$} & Sex (Female) & 0.035 & $14.43[25.02-8.33]$ & 0.009 & Sex (Male) \\
\hline & Age $^{a}$ & 0.042 & 1.24 [1.47-1.05] & 0.010 & \\
\hline & $\begin{array}{l}\text { Time since last } \\
\text { chemotherapy }\end{array}$ & 0.111 & & & \\
\hline & Miscellany & 0.012 & & & $\begin{array}{l}\text { Not having been } \\
\text { treated with } \\
\text { this drug type }\end{array}$ \\
\hline & $\begin{array}{l}\text { Frequency of } \\
\text { chemotherapy } \\
\text { doses }^{c}\end{array}$ & 0.210 & & & \\
\hline & Creatinine $^{\mathrm{d}}$ & 0.116 & & & \\
\hline & Leukocytes e & 0.181 & & & \\
\hline & Age $^{a}$ & 0.101 & & & \\
\hline \multirow{4}{*}{$2^{\text {nd }}$} & $\begin{array}{l}\text { Time since last } \\
\text { chemotherapy }^{b}\end{array}$ & 0.143 & & & \\
\hline & Miscellany & 0.009 & $6.39[7.80-5.77]$ & 0.009 & $\begin{array}{l}\text { Not having been } \\
\text { treated with } \\
\text { this drug type }\end{array}$ \\
\hline & $\begin{array}{l}\text { Frequency of } \\
\text { chemotherapy } \\
\text { doses }^{c}\end{array}$ & 0.132 & & & \\
\hline & Platelets ${ }^{\mathrm{f}}$ & 0.150 & & & \\
\hline \multirow{4}{*}{$3^{\text {rd }}$} & $\begin{array}{l}\text { Alkylating } \\
\text { agents }\end{array}$ & 0.278 & & & $\begin{array}{l}\text { Not having been } \\
\text { treated with } \\
\text { this drug type }\end{array}$ \\
\hline & Antimetabolites & 0.125 & & & $\begin{array}{l}\text { Not having been } \\
\text { treated with } \\
\text { this drug type }\end{array}$ \\
\hline & $\begin{array}{l}\text { Natural } \\
\text { Products }\end{array}$ & 0.265 & & & $\begin{array}{l}\text { Not having been } \\
\text { treated with } \\
\text { this drug type }\end{array}$ \\
\hline & $\begin{array}{c}\text { Frequency of } \\
\text { chemotherapy } \\
\text { doses }^{c}\end{array}$ & 0.281 & & & \\
\hline \multirow{3}{*}{$4^{\text {th }}$} & $\begin{array}{l}\text { Time since last } \\
\text { chemotherapy }\end{array}$ & 0.237 & & & \\
\hline & $\begin{array}{l}\text { Natural } \\
\text { Products }\end{array}$ & 0.265 & & & $\begin{array}{l}\text { Not having been } \\
\text { treated with } \\
\text { this drug type }\end{array}$ \\
\hline & Creatinine $^{\mathrm{d}}$ & 0.093 & & & \\
\hline
\end{tabular}


Additionally, an association between Antimetabolites a class of chemotherapeutic drugs with potential stomatotoxicity and increased blood creatinine was observed, and these drugs were found to enhance the stomatotoxic effects of the antineoplastic protocols $(2,25)$. Xu et al. (23) monitored the blood concentration of methotrexate, one of the most commonly used drugs in the $6^{\text {th }}$ evaluation week (consolidation of remission occurred at 6 weeks) in patients with Acute Lymphoblastic Leukemia and Non-Hodgkin lymphoma in remission and confirmed the hypothesis that the clearance of creatinine in the blood can reduce the toxicity of Methotrexate in the body. The effects of methotrexate in the body are highly concerned (23), and this drug is regarded as one of the most stomatotoxics. The blood concentration of this drug has also been associated with increase of

Table 5. Univariate and multiple analysis for occurrence of severe oral mucositis in pediatric patients with solid tumors ( $\mathrm{n=51)}$. João Pessoa, Paraíba, Brazil, 2017 (cont.)

\begin{tabular}{|c|c|c|c|c|c|}
\hline \multirow{2}{*}{$\begin{array}{l}\text { Treatment } \\
\text { week }\end{array}$} & \multicolumn{2}{|c|}{ Univariate analysis } & \multicolumn{2}{|c|}{ Multiple analysis } & \multirow{2}{*}{$\begin{array}{c}\text { Reference } \\
\text { category }\end{array}$} \\
\hline & Variable & $\mathrm{p}$-value & OR [CI95\%] & p-value & \\
\hline \multirow{5}{*}{$5^{\text {th }}$} & $\begin{array}{l}\text { Time since last } \\
\text { chemotherapy }{ }^{b}\end{array}$ & 0.151 & & & \\
\hline & Antimetabolites & 0.038 & $17.44[23.85-12.75]$ & 0.019 & $\begin{array}{l}\text { Not having been } \\
\text { treated with } \\
\text { this drug type }\end{array}$ \\
\hline & $\begin{array}{l}\text { Natural } \\
\text { Products }\end{array}$ & 0.095 & & & $\begin{array}{l}\text { Not having been } \\
\text { treated with } \\
\text { this drug type }\end{array}$ \\
\hline & Miscellany & 0.187 & $45.42[55.53-37.15]$ & 0.008 & $\begin{array}{l}\text { Not having been } \\
\text { treated with } \\
\text { this drug type }\end{array}$ \\
\hline & Platelets ${ }^{\mathrm{f}}$ & 0.012 & $1.12[1.21-1.02]$ & 0.003 & \\
\hline \multirow[t]{2}{*}{$6^{\text {th }}$} & Miscellany & 0.019 & & & $\begin{array}{l}\text { Not having been } \\
\text { treated with } \\
\text { this drug type }\end{array}$ \\
\hline & Creatinine $^{\mathrm{d}}$ & 0.016 & 1.63 [2.44-1.09] & 0.016 & \\
\hline \multirow{3}{*}{$7^{\text {th }}$} & Sex & 0.256 & & & \\
\hline & Leukocytes ${ }^{\mathrm{e}}$ & 0.069 & & & \\
\hline & Creatinine $^{d}$ & 0.001 & 2.39 [4.13-1.39] & 0.001 & \\
\hline \multirow{4}{*}{$8^{\text {th }}$} & $\begin{array}{l}\text { Time since last } \\
\text { chemotherapy }\end{array}$ & 0.132 & & & \\
\hline & $\begin{array}{l}\text { Frequency of } \\
\text { chemotherapy } \\
\text { doses }^{c}\end{array}$ & 0.131 & & & \\
\hline & Platelets ${ }^{\mathrm{f}}$ & 0.057 & & & \\
\hline & Creatinine $^{d}$ & 0.159 & & & \\
\hline $9^{\text {th }}$ & Miscellany & 0.268 & & & $\begin{array}{l}\text { Not having been } \\
\text { treated with } \\
\text { this drug type }\end{array}$ \\
\hline $10^{\text {th }}$ & Miscellany & 0.122 & & & $\begin{array}{l}\text { Not having been } \\
\text { treated with } \\
\text { this drug type }\end{array}$ \\
\hline
\end{tabular}

${ }^{a}=$ For each increase of 1 -year; ${ }^{b}=$ For each increase of 1 -day; ${ }^{c}=$ For each increase of 1 -dose; ${ }^{d}=$ For each increase of 0.1-unit in the blood concentration; ${ }^{\mathrm{e}}=$ For each reduction of 1,000 -leukocytes; $\mathrm{f}=$ For each reduction of 10,000-platelets. OR=Odds Ratio; CI=Confidence Interval. The increase or the reduction in blood components were evaluated considering the normal parameters for pediatric patients. 
creatinine level in the blood (25).

The occurrence of oral mucositis is associated with several factors, and within the reality of a public health institution, the addition of the analysis of a genetic factor or oral microbiological investigation of a predictive model would not make the prediction of SOM feasible because of the high costs of these periodic assessments. Therefore, although the genetic component, the oral microbiota, and the degree of malnutrition in patients were not evaluated in the present study, all potential variables cited in classical and recent studies $(4,14,15,21)$ and liable to be easily identified in medical records (records of prescriptions and blood tests) were evaluated and included in this study.

In this study was possible to identify that the frequency of administration of chemotherapy doses is more important in the emergence of the Severe oral mucositis in the patients with hematologic neoplasms, and that the chemotherapeutic agents of Miscellany and Antimetabolites classes are more important for increased risk for Severe oral mucositis in the patients with solid tumors. It is important to observe that the high mortality rate among cancer patients younger than 15 years was associated with the occurrence of SOM $(15,1 \%)$ compared with the rate in patients with moderate oral mucositis (7.4\%) during the induction/intensification phase of chemotherapy (19). The results of this study should be carefully evaluated to guide the decision-making process with respect to the health care that should be provided to children and adolescents diagnosed with cancer, particularly in the early stages of treatment.

Our study suggests that: for the patients with hematologic neoplasms, to be female and the increased of frequency of chemotherapy doses increased the risk for SOM; and for patients with solid tumors, to be female, the increased in age and in level blood concentration of creatinine, the platelets reduction and the use of chemotherapy with Miscellany and Antimetabolites agents are associated with increased risk for SOM and this should be given greater attention based on the estimated risks associated with these factors.

These findings of this study demonstrate that for patients with hematologic tumors, the frequency of administration of chemotherapeutic agents has a greater influence on the risk for severe oral mucositis and, for patients with solid tumors, is the type of chemotherapy that have the same influence, as does the increase in age and creatinine blood levels. For both tumor groups, females are more likely to develop of Severe oral mucositis. These aspects are important to know about factors that influence the appearance of Severe oral mucositis in each tumor group and to consider about ways of prevention, surveillance and action at the slightest signs of inflammation in the oral mucosa. For patients with hematologic tumors, our findings suggest need of increase in oral health care for patients in $6^{\text {th }}$ and $7^{\text {th }}$ weeks of treatment ( $2^{\text {nd }}$ month of treatment), due to the influence of administration frequency of chemotherapeutic agents. For patients with solid tumors, the present study suggests that greater attention should be given to patients treated with the Miscellaneous and Antimetabolites classes, and to those whose the creatinine blood levels are increased, especially in the first seven weeks of treatment.

\section{Resumo}

Este estudo objetivou avaliar os fatores associados com a ocorrência de mucosite oral grave (SOM) em pacientes pediátricos oncológicos durante o tratamento quimioterápico. Trata-se de um estudo de caso-controle aninhado a uma coorte prospectiva que monitorou 105 pacientes por 10 semanas consecutivas após o início do tratamento quimioterápico. Regressão logística foi utilizada para identificar os fatores associados com a MOG, por grupo de malignidade (tumores hematológicos ou sólidos) (Sig. $=5 \%$ ). Para pacientes com tumores hematológicos foram encontrados fatores associados com a MOG em duas semanas de tratamento: na $6^{\text {a }}$ semana (aumento na frequência de doses de quimioterapia $(O R=3,02)$ )

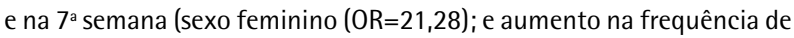
doses de quimioterapia $(\mathrm{OR}=2,51))$; e para pacientes com tumores sólidos foram encontrados fatores associados com MOG em cinco semanas de tratamento: na $1^{\text {a }}$ semana (sexo feminino $(O R=14,43)$, aumento na idade $(\mathrm{OR}=1,24))$; na $2^{\text {a }}$ semana (Miscelânea $\left.(\mathrm{OR}=6,39)\right)$; na $5^{\text {a }}$ semana (Antimetabólitos $(O R=17,44)$; Miscelânea $(O R=45,42)$; e redução de

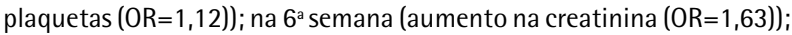
e na 7 a semana (aumento na creatinina $(\mathrm{OR}=2,39)$ ). Para pacientes com tumores hematológicos, ser do sexo feminino e $o$ aumento na frequência

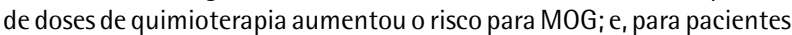
com tumors sólidos, ser do sexo feminino, o aumento na idade e nos niveis de concentração sanguinea de creatinina, a redução no número de plaquetas e o uso de quimioterapia com agentes das classes Miscelânea e Antimetabólitos estiveram associados com o aumento no risco para a ocorrência de MOG.

\section{References}

1. Cheng $\mathrm{KK}$, Lee $\mathrm{V}$, Li CH, Yuen $\mathrm{HL}$, Epstein JB. Oral mucositis in pediatric and adolescent patients undergoing chemotherapy: the impact of symptoms on quality of life. Support Care Cancer 2012;20:23352342.

2. Mendonça RM, Araújo Md, Levy CE, Morari J, Silva RA, Yunes JA, et al. Oral mucositis in pediatric acute lymphoblastic leukemia patients: evaluation of microbiological and hematological factors. Pediatr Hematol Oncol 2015;32:322-330.

3. Peterson DE, Srivastana R, Lalla RV. Oral mucosal injury in oncology patients: perspectives on maturation of a field. Oral Dis 2015;21:133141.

4. A.Y.H Kung, S Zhang, L.W Zheng, G.H.M Wong, C.H. Oral health status of chinese paediatric and adolescent oncology patients with chemotherapy in hong kong: a pilot study. Open Dent J 2015;9:21-30.

5. Cheng KKF, Chang AM, Yuen MP. Prevention of oral mucositis in paediatric patients treated with chemotherapy: a randomised crossover trial comparing two protocols of oral care. Eur J Cancer 2004;40:1208-1216.

6. Villa A, Sonis ST. Mucositis: pathobiology and management. Curr Opin Oncol 2015;27:159-164.

7. Barkokebas A, Silva IH, de Andrade SC, Carvalho AA, Gueiros LA, Paiva SM, et al. Impact of oral mucositis on oral heal the related quality of life of patients diagnosed with cancer. J Oral Pathol Med 2015;44:746-751.

8. Ahmed KM, Abdulla BK, Saber TK, Alrahman MSA. Risk factors of 
oral mucositis in pediatric patients (less than 18 years old) receiving chemotherapy. Int J Sci Res 2016;4:245-249.

9. Amadori F, Bardellini E, Conti G, Pedrini N, Schumacher RF, Majorana A. Low-level laser therapy for treatment of chemotherapy-induced oral mucositis in childhood: a randomized double-blind controlled study. Lasers Med Sci 2016;31:1231-1236.

10. Cheng KK, Goggins WB, Lee VW, Thompson DR. Risk factors for oral mucositis in children undergoing chemotherapy: a matched casecontrol study. Oral Oncol 2008;44:1019-1025.

11. Vishwanatha A, D'Souza CJM. Multifaceted effects of antimetabolite and anticancer drug, 2 deoxyglucose on eukaryotic cancer models budding and fission yeast. IUBMB Life 2017;69:137-147.

12. Singh RK, Kumar S, Prasad DN, Bhardwaj TR. Therapeutic journery of nitrogen mustard as alkylating anticancer agents: Historic to future perspectives. Eur J Med Chem 2018;151:401-433.

13. Mignani S, Rodrigues J, Tomas $H$, Zablocka M, Shi $X$, Caminade A, et al. Dendrimers in combination with natural products and analogues as anti-cancer agents. Chem Soc Rev 2018;47:514-532.

14. Apps MG, Choi EHY, Wheate NJ. The state-of-play and future of platinum drugs. Endocr Relat Cancer 2015;22:219-233.

15. Nascimento PBL, Santos LCO, Carvalho CN, Alves CAL, Lima SM, Cabral MMS. Oral manifestations in hospitalized children and adolescents subjected to antineoplastic therapy. Brazilian Research in Pediatric Dent Int Clin 2013;13:279-285.

16. Ip WY, Epstein JB, Lee V, Yuen HL, Li R, Thompson DR, et al. Oral mucositis in paediatric patients after chemotherapy for cancer. Hong Kong Med J 2015;20:4-8.

17. Javed F, Utreja A, Bello Correa FO, Al-Askar M, Hudieb M, Qayyum F et al. Oral health status in children with acute lymphoblastic leukemia. Crit Rev Oncol Hematol 2012;83:303-309.

18. Asselin BL, Devidas M, Chen L, Franco VI, Pullen J, Borowitz MJ, et al. Cardioprotection and safety of dexrazoxane in patients treated for newly diagnosed t-cell acute lymphoblastic leukemia or advanced- stage lymphoblastic non-hodgkin lymphoma: a report of the children's oncology group randomized trial pediatric oncology group 9404. J Clin Oncol 2015;34:854-863.

19. Anirudhan D, Bakhshi S, Xess I, Broor S, Arya LS. Etiology and outcome of oral mucosal lesions in children on chemotherapy for acute lymphoblastic leukemia. Indian Pediatr 2008;45:47-51.

20. Meeske KA, Ji L, Freyer DR, Gaynon P, Ruccione K, Butturini A. Comparative toxicity by sex among children treated for acute lymphoblastic leukemia: a report from the children's oncology group. Pediatr Blood Cancer 2015;62:2140-2149.

21. Scully C, Epstein J, Sonis S. Oral mucositis: a challenging complication of radiotherapy, chemotherapy, and radiochemotherapy: part 1 , pathogenesis and prophylaxis of mucositis. Head Neck 2003;25:10571070.

22. Sonis ST. Mucositis: the impact, biology and therapeutic opportunities of oral mucositis. Oral Oncol 2009;45:1015-1020.

23. Xu WQ, Zhang LY, Chen $X Y$, Pan BH, Mao JQ, Song $H$, et al. Serum creatinine and creatinine clearance for predicting plasma methotrexate concentrations after high-dose methotrexate chemotherapy for the treatment for childhood lymphoblastic malignancies. Cancer Chemother Pharmacol 2014;73:79-86.

24. Tsurusawa M, Gosho M, Mori T, Mitsui T, Sunami S, Kobayashi R, et al. Statistical analysis of relation between plasma methotrexate concentration and toxicity in high dose methotrexate therapy of childhood nonHodgkin Iymphoma. Pediatr Blood Cancer 2015;62:279-284.

25. Yang SL, Zhao FY, Song H, Shen DY, Xu XJ. Methotrexate associated renal impairment is related to delayed elimination of high-dose methotrexate. Sci World J 2015;2015:1-8.

Received October 7, 2019 Accepted November 6, 2019 